\title{
Virtual Classrooms in Brazil: teachers' difficulties and anxieties towards technology in language leaming
}

\author{
Andréa Machado de Almeida Mattos \\ Universidade Federal de Minas Gerais
}

\begin{abstract}
Atualmente, muitos pesquisadores têm promovido entusiasticamente as vantagens de se introduzir tecnologia na sala de aula de língua estrangeira (LE), mas poucos têm-se preocupado com os problemas e as ansiedades que resultam de mudanças numa cultura tão antiga quanto a da sala de aula de LE. Este trabalho visa a discutir os problemas enfrentados por professores que trabalham com tecnologia em suas salas de aula de língua. A pesquisa foi baseada em estudos teóricos e empíricos tanto na área de ensino mediado por computador quanto no campo de desenvolvimento de professores. 0 objetivo principal deste trabalho é, assim, obter um entendimento global das ansiedades do professor em relação ao ambiente virtual de aprendizagem de língua. Os dados foram coletados mediante entrevistas com os professo res informantes, levando a uma análise qualitativa dos resultados.
\end{abstract}

Many researchers, nowadays, have been enthusiastic in promoting the advantages of introducing technology in the language classroom, but few have been worried with the problems and anxieties that result from changes in a long-lasting culture such as the culture of language learning. This paper aims at discussing the problems faced by teachers who have been working with technology in their language classrooms. The research design was based on theoretical and empirical studies both in the areas of Computer Assisted Language Learning and Teacher Development. The main objective of this paper is, thus, to achieve a global understanding of the teachers' anxieties in relation to the virtual environment of language learning. Data was gathered through interviews with the teachers, leading to a qualitative analysis of the findings. 
"Teachers have to be viewed as individuals who learn, shape, and are shaped by the activity of teaching." (Freedman et al., in Freeman, 1996a: 353)

\section{Introduction}

The recent advances in Information and Communication Technology (ICT) have brought an innovative perspective to all areas in the beginning of this new millennium. Nowadays, the computer is being used with high frequency in every field, including the fields of Education and Language Teaching. Thus, ICT and computers exert a high influence on the development of new techniques for teaching and learning languages. The traditional ${ }^{1}$ language classroom, as we all know it, is now being invaded by numerous new approaches and teaching/ learning resources involving the Internet and Computer Assisted Language Learning (CALL), generating significant changes in the roles of both teachers and learners. Although the Internet and CALL open a wide range of totally new possibilities for language teachers and learners, the introduction of this new tool into the long-lasting culture of the language classroom is not a simple issue. As Postman (according to AZEVED O, 2000:2) has pointed out, "it is a mistake to suppose that every technological innovation has only a unilateral effect. Every technology is as much a burden as it is a blessing."

For this reason, it is important to prepare teachers for the new roles they have been required to assume when introducing new technologies into their language classrooms. Thus, the aim of this paper is to try to find out some of the perceptions teachers have in relation to the use of computers in both traditional and virtual classrooms, in order to discuss the problems and anxieties they face in assuming the

\footnotetext{
${ }^{1}$ What is meant by "traditional" here does not refer to the choice of methodology used or to the type of theory that underlies this choice, but to the physical environment of the classroom as a place where students meet at a specific time of the day to learn language mostly from the teacher and other classroom materials which do not make use of any technological apparatus other than cassette players. This idea contrasts both with the use of computer laboratories as language classrooms and also with the idea of virtual or on-line classrooms, which use the computer as the medium of instruction.
} 
new roles which result from the use of technology. The ultimate objective is to raise awareness towards teachers' problems and anxieties and start looking for ways to help them cope with the requirements of CALL. First, some important issues in teacher education and development will be revised, as well as some of the most prominent works in CALL, both in Brazil and abroad. The research design and methodology will, then, be presented, followed by a brief discussion of the procedures for data collection and analysis. Finally, results will be presented and discussed. It will be argued that the results of this research bring implications to the field of CALL, especially to teachers working in developing countries, such as Brazil, where the study was carried out.

\section{Theoretical background}

As stated above, the design of this research paper is tw ofold: the research was based on theoretical and empirical studies on teacher education and development (TE/TD) and on CALL. These two different backgrounds will be briefly discussed below.

\section{Teacher education and development}

During the last two decades, a number of researchers all over the world have been interested in studying the second language teacher. Notably, from the publication of the article "Teacher Training, Development, and Decision Making: a model of teaching and related strategies for language teacher education" (FREEMAN, 1989) and the book "Second Language Teacher Education" (RICHARDS \& NUNAN, 1990), a new trend in language teacher education was started (FREEMAN \& RICHARDS, 1996). At this time, the most prominent researchers who were interested in teacher education in Brazil were Almeida Filho (1997), Gimenez (1994) and Moita Lopes (1996).

Research on teacher education and development quickly evolved and went through several changes in terms of perspective. According to Freeman (1996b), this type of research may be grouped into three different trends, depending on the points of view assumed by the researcher and the importance of the contributions of the participant teacher: the behavioral view, the cognitive view and the interpretivist view. The behavioral view, as the name suggests, focuses on the behavior of the teacher inside the classroom. In this view, the researcher 
is the observer of what teachers do in the classroom and teachers' actions are frequently related to what students learn as a result. The cognitive view focuses on the teachers' mental processes, their perceptions and intentions, their beliefs, knowledge and attitudes, as well as the affective dimensions (such as feelings of anxiety and fear) which are undoubtedly present in their daily practice, shaping their thoughts and actions. This view is commonly referred to as "research on teacher cognition" or "teacher thinking" (WOODS, 1996), and it tries to relate what teachers think before lessons ("pre-active decision") with what they think during lessons ("interactive decisions") (FREEMAN, 1996b). An alternative trend, the interpretivist view, is suggested by Freeman, aiming at understanding how teachers interpret their own practice in relation to the specific context they work in. This new perspective tries to cater not only for the researcher's conclusions but also for the voices of the participant teachers.

O ne of the persisting worries of researchers in the field of language teacher education is the issue of the non-native foreign language teacher. The dichotomy between native and non-native speakers $^{2}$ of a certain language dates back to the origins of the studies in Modern Linguistics, when Chomsky (1965) introduced the notion of "native speaker competence" (STERN, 1988). Initially, the need to imitate the native speaker's performance has dominated the goals of $\mathrm{FL}$ teachers and learners as well. Nowadays, this is no longer as important, although the issue hasn't been totally dismissed. Almost thirty years later, in a book called "The Non-native Teacher", Medgyes (1994) reopens the discussion around this controversial aspect of language teaching. The author discusses the main differences in attitude between native and non-native teachers of English as a Foreign Language (EFL), and the advantages and disadvantages of being a nonnative teacher. He gives special emphasis to the main problems faced by non-native EFL teachers, such as the language deficit and an inferiority complex towards native speakers. As a consequence, Medgyes states that the teacher may enter a stress cycle that may lead

\footnotetext{
${ }^{2}$ LIGHTBO WN \& SPADA (1993:124) define the native speaker as "a person who has learned a language from an early age and who has full mastery of that language". In contrast, the non-native speaker is the one who has learned the target language after childhood and whose command of the target language presents limitations.
} 
to decreased performance and bad feelings of underachievement. The work overload may also contribute to raise teacher stress, causing tension and feelings of self-blame, which can lead the teacher to isolation or even cause health problems. Claxton, cited in Medgyes (1994), illustrates the stress cycle as represented in FIG. 1.

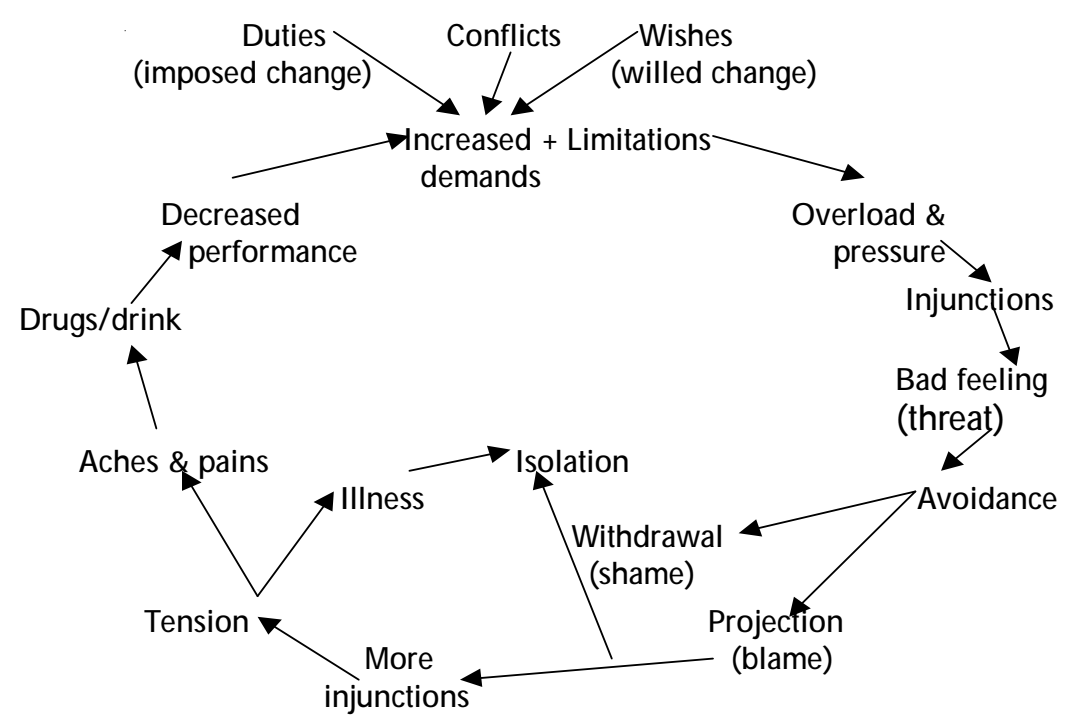

FIGURE 1 - Claxton's Stress Cycle (cited in MEDGYES, 1994:42)

Based on Freeman's suggestions for interpretivist views of research on teacher development, Mattos (2000) reports on a research study which focused on the informant teacher's perceptions of her own classroom events. Aiming initially at a global comprehension of the teacher's perceptions, the findings also revealed an insightful set of elements which may influence the foreign language teacher's daily life. The research data was collected through a series of retrospective interviews with the informant teacher, who reflected on her classroom events with the help of a video recording of her classes. The interviews were transcribed and analyzed, giving rise to a list of reflective categories. ${ }^{3}$

One of the dominant categories in the list was labeled "the context" and represented a picture of the elements which influence the $\mathrm{FL}$

\footnotetext{
${ }^{3}$ For a better understanding of the concept and a deeper discussion of such categories, please refer to MATTOS (2000 and 2002)
} 
teachers' daily life. Through the retrospective interviews, the informant teacher revealed that her classroom performance was influenced by a number of different elements, which may be either a positive or a negative influence or may take the form of pressures originated inside or outside the classroom. For example, as one positive influence on her classroom performance, the teacher mentioned "how the students' previous (good) learning experiences may favor the student-teacher relationship" and, as a negative influence, she mentioned "how the (bad) learning experiences affect the teaching process" (MATTOS, 2000: 80). The classroom pressures were subdivided into pedagogic pressures (such as timing and unpredicted problems), interaction pressures (such as students' image of the teacher), personal pressures (such as selfdemanding and the teacher's other private activities) and contextual pressures (such as the evaluation system and the need to fulfill the course program). These several elements which influence the FL classroom were represented as shown in FIG. 2 below.

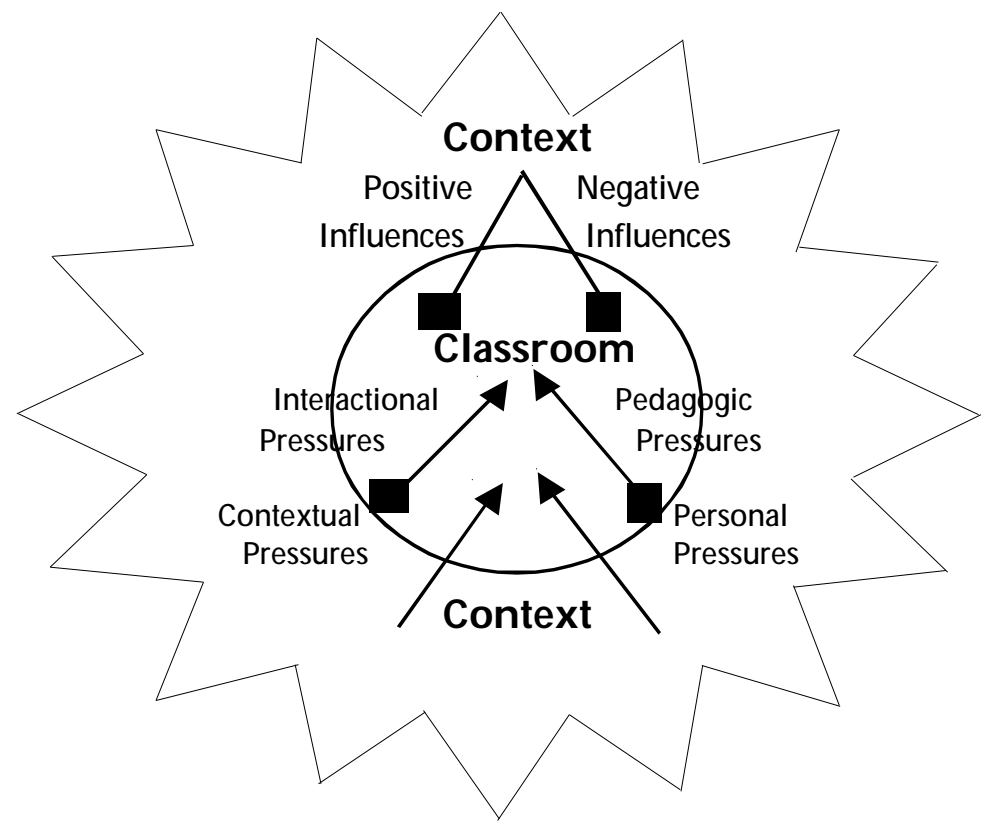

FIGURE 2 - Elements which influence the FL classroom (MATTOS, 2000:88)

In the above figure, as discussed in Mattos (2000), the big external star-shaped area represents the context in which the classroom is found. 
Because it is fluid and unlimited by nature, the context is represented by a broken line. The several tips of the star try to represent the contextual differences found in the various FL teaching situations. The internal circle symbolizes the FL classroom which is represented by a continuous black line because it is a closed culture, which is not accessible to the outside observer (HOLLIDAY, 1994) or a "black box" (LONG, 1980). The reported results ratify Medgyes' ideas on the problems faced by non-native EFL teachers.

\section{Computer assisted language learning}

According to Paiva (2001a), the Internet derives from an electronic netw ork created in 1969 by the American Defense Department with the objective of sharing secret information in a safe way. This network was capable of transferring a big amount of data from one computer to another with great speed. The World Wide Web (WWW), though, was only started in 1991 (PAIVA, 2001a: 94). Schools soon began to use the Internet and the WWW as a supporting tool for traditional methods and teachers of English as a second or foreign language also began to exploit the information available on the web in their courses.

Paiva, one of the most prominent researchers in the area of CALL in Brazil, who has been a constant spreader of the use of technology in language classrooms, ${ }^{4}$ suggests that "the resources available on the web, because they are non-linear and multidimensional, may offer learners a richer environment for the acquisition of English than traditional materials" (PAIVA, 2001a: 96). In tune with this line of thought, HansonSmith (2001: 107) states that "the widespread use of software, [... ] and the Internet have created enormous opportunities for learners to enhance their communicative abilities, both by individualizing practice and by tapping into a global community of other learners."

Most authors, how ever, recognize that technology has both good and bad things to offer learners and teachers alike. Graus (1999) shows that, in terms of organization, the Internet has a wide variety of resources that may be used by language teachers, but there is no organized or coherent structure, and there is no guarantee that teachers will find what they are looking for. In terms of accessibility, G raus says that users usually don't have problems with the Internet because most

\footnotetext{
${ }^{4}$ See, for instance, PAIVA $(2001 a, b)$
} 
systems have information services that help users solve their problems, but the author also reminds us that, with the growth of interest and popularity, the systems are often jammed and some resources may become very slow. In terms of pedagogy, the most obvious advantage of the Internet is the availability of authentic materials, making the learning process more real and attractive. Besides, learners are allowed to choose the most convenient materials for their own purposes, which promotes autonomy and self-development. On the other hand, not all information found on the net is appropriate, relevant or even desirable, causing distraction and sometimes even hindering the learning process.

Paiva (2001a) also recognizes that the use of technology in EFL classrooms may have advantages and disadvantages. The following table summarizes her views on the pros and cons of the Web:

TABLE 1

\begin{tabular}{|c|c|}
\hline Positive points of the Web & Negative points of the Web \\
\hline Variety of information & Excess of information \\
\hline Possibility of constant update & Lack of update of some sites \\
\hline $\begin{array}{l}\text { Multimedia environment: image, } \\
\text { sound, video }\end{array}$ & $\begin{array}{l}\text { Slow transferring of information } \\
\text { in relation to the amount of resources }\end{array}$ \\
\hline Easy browsing & Necessity of constant update of softw are \\
\hline Diversity of material & Low quality of some materials \\
\hline $\begin{array}{l}\text { Possibility to choose the } \\
\text { information needed }\end{array}$ & Not all information is reliable \\
\hline $\begin{array}{l}\text { Individual responsibility in } \\
\text { choosing the information }\end{array}$ & $\begin{array}{l}\text { Excess of options, making the choice } \\
\text { difficult }\end{array}$ \\
\hline Free information & Expensive telephone taxes \\
\hline Fostering of continuing education & Not all courses are free \\
\hline Q uick access to information & Information is not always found \\
\hline $\begin{array}{l}\text { Access to in-construction texts } \\
\text { building }\end{array}$ & Some sites may stay in constant \\
\hline Limitless time & Some sites disappear quickly \\
\hline Possibility of access to authors & Some sites are anonymous \\
\hline $\begin{array}{l}\text { Reading is organized by } \\
\text { brow sing maps }\end{array}$ & Some sites are disorganized \\
\hline Possibility of non-linear reading & Hypertexts may be distracting \\
\hline
\end{tabular}

Adapted from Paiva (2001a:99) 
Although there are problems and disadvantages in the use of the Internet and the WWW in language learning, many researchers are in favor of introducing technology into the language classroom. Some of the best-known names in the area of CALL are, for example, Warschauer (1995 and 2000), Debski et al (1997), Levy (1997) and Beaugrande (2002). These authors have been promoting research that advocates the use of technology as a tool which fosters the acquisition of a second or foreign language both when used as support materials in traditional classrooms and when virtual classrooms are created. In traditional classrooms, teachers may use the Internet resources as supporting materials to their classes. In virtual classrooms, the Internet is used as a means of communication between participants (teachers and learners) through the use of e-mail, discussion lists or e-groups.

It seems, however, that all these authors and researchers have only been worried about the benefits and problems of introducing technology in EFL classrooms from the perspective of the learner. The teacher has not yet played an important role as informant of such research. It is important to remember that any innovation brings along several changes in the roles of participants in the culture and it may sometimes be difficult to adapt to all these changes.

After the advance of CALL, the language classroom will certainly never be the same. Many people have been wondering how much longer traditional classrooms and materials will still resist. In fact, it has been said that traditional teachers and approaches ${ }^{5}$ will not be substituted by any technological apparatus, but teachers who are against using technology in their classrooms will be substituted for those who are inclined to doing so.

Thus, the Internet and CALL have come to stay. In Brazil, there are thousands of different courses being offered on the net, and new ones are created every term. Distance learning has gone through a new boom with the creation of the Public Virtual University of Brazil UNIREDE, a pool involving more than 60 different institutions, with the objective of offering undergraduate courses for unqualified primary teachers. The discussion raised over the problems that might come up involves questions about evaluation issues, the efficiency of a totally

\footnotetext{
${ }^{5}$ Please, refer to endnote 1.
} 
on-line undergraduate course, and whether there will be enough teachers prepared to interact with students (VIEIRA, 2002).

From the point of view of the learners, distance learning has some advantages, such as studying at home, at any time, the possibility of reviewing messages before posting them, the possibility of interacting with other learners from different places (cultural interaction) and with the teacher at any time before or after lessons, to mention only a few (PAIVA, 2001b). From the point of view of the teachers, however, on-line teaching brings, together with the advantages, several problems that must be taken into account. It is certainly an increase to their work load. On-line interaction is more time-consuming because participants must make extra efforts to be understood, without the aid of visual communication (gestures and facial expressions) and the phonological aspects of the language (intonation). The number of interactional turns increases, since all participants may interact at the same time. It requires, then, a lot of supervision on the side of the teacher (PAIVA, 2001b). As a consequence, teachers feel more stressed with the increase of the pressures on their virtual classrooms. This situation reflects Mattos' (2000) findings concerning the factors which influence the language classroom and Medgyes' (1994) ideas about the teaching stress cycle.

Carvalho (2001) and Gariglio (2001) call the computer a Pandora's Box, and Coura Sobrinho (2001) further compares it to a "black box" (LONG, 1984), in an allusion to all the problems that might arise together with the benefits. Basically, all three authors call attention to the new roles assumed by the teacher in a CALL environment. Kook (1997:59) asserts that "the role of teachers will continue to evolve from dispenser of information to facilitators of learning". Additionally, the teacher will also sometimes be called upon to give technical support to those students who might not be familiar with the technology (COURA SO BRINHO , 2001). Gariglio (2001) asks whether teachers are prepared for their new roles: are teachers willing to step out of the central educational scene? Are they prepared to leave their privileged roles of "experts" and providers of knowledge to become "mere" facilitators in the learning process?

An insightful work in the area of teachers' difficulties and anxieties towards technology in teaching EFL is reported by Corrêa (2002). The author describes the perceptions of two English teachers about their own classrooms and the problems they had in working with CALL. 
As it has been demonstrated through the work of several authors cited above, it is necessary to explore not only the benefits of CALL but also the problems that teachers might have when trying to introduce technological changes into their teaching practice. It is important to have a clear view of the problems and difficulties teachers find in dealing with CALL, so that teacher education programs can start preparing teachers for the new requirements they are certainly going to face. The research study reported below is a step in this direction.

\section{Informants and Data Collection Processes}

This research study was conducted through a series of short online interviews ${ }^{6}$ with five informant teachers who have been working with CALL. In order to preserve their anonymity, here they will be referred to as $\mathrm{T} 1, \mathrm{~T} 2, \mathrm{~T} 3, \mathrm{~T} 4$ and $\mathrm{T} 5$. O ne of these teachers (T1) is very experienced in the field and has been working with CALL in both real and virtual classrooms for about 5 years. The other four teachers are also very experienced teachers but have only worked with CALL in their classrooms for one or two years in average. Four of the informants have worked with CALL at university level and only one of them (T4) has been using CALL at the secondary school level. They are all engaged in developing different research projects in the field of CALL, investigating both virtual environments and the use of technology in real classrooms.

During the interviews, the informants were asked to briefly describe their teaching practices and how they became interested in the use of technology in language teaching. Answers to this part of the interview ranged from personal experiences as students in a virtual environment to an interest in the area of CALL for their M.A. research projects. The different reasons teachers had for entering the field of CALL were not considered relevant for the objectives of this research. Therefore, they will not be discussed here. The rest of the interview questions were aimed at uncovering the different problems informants might have faced in dealing with technology in their teaching. The questions were formulated in different ways but were basically the following:

\footnotetext{
${ }^{6}$ There was no fixed number of interviews per informant. Each informant was contacted once through a set of initial questions and further questions were asked, as necessary, in order to clarify participants' views.
} 
- How did you become interested in CALL?How long ago was that?

- What kind of work do you do nowadays involving the use of technology in language teaching?

- What advantages do you see in the use of technology in real or virtual classrooms?

- What problems have you faced in your practice with CALL?

- What changes do you see in the role of the teacher in virtual classrooms?

- How do you feel as a teacher in a virtual environment?

\section{Research Findings}

The informants' answers to the interviews were analyzed qualitatively in search of insights into the teachers' problems and anxieties in working with technology in language teaching. The results of the analysis showed that the teachers are faced with different problems when dealing with CALL. These problems were divided into two categories:

- problems related to the technology;

- problems related to the virtual environment.

In the first category, the informant teachers mentioned several problems related to the equipment, such as old computers, and problems users find in accessing the Internet. Lack of technological support and students' illiteracy in the use of technology were also included in this category.

In relation to the second category, the informant teachers mentioned several different problems, which include the increase in teachers' work, unlimited contact with students, lack of face-to-face interaction, change in the role of the teacher, students' resistance, and prejudice against on-line courses.

As examples of the first category, problems related to the technology, T1 mentioned the following:

T1 - "The biggest problem is the lack of good equipment and of technological support. You offer a course involving listening and the student doesn't have audio equipment in the lab or at home. If you want to work in the evening at the university, and you have any problem with the network, there is no technical support available, because the technical staff doesn't w ork in the evening." 
This same teacher also said:

T1 - "In addition to the questions related to the content of the course, the students also ask for your support with the technology, mainly those who are less experienced with the computer."

Three other teachers also mentioned problems related to the technology. The excerpts below are examples of what they complained about:

T2 - "Technology is dilatory: connections are slow and there are many break-downs."

T3 - "The most common difficulties are linked to physical issues: connecting problems; and the students don't have access to the ww w outside the classroom."

T4 - "The biggest problem is the technology in itself. Connecting problems, slow computers and software which doesn't work properly are frequent. This possibility demands extra work from the teacher who must always have extra activities prepared in advance to cater for these problems."

As for the second category, problems related to the virtual environment, the following excerpts are examples of what the informant teachers said:

T1 - "The problems the teacher faces are: increase in the work load, since there is more interaction and the contact with the students is not limited to the weekly four hours, as in standard classes."

T3 - "Learners are resistant to the use of communication technology in teaching."

T4 - "Another issue that demands extra time from the teacher is the search for instructional material which is adequate to his/her educational objective and the organization of this material in order to make it pedagogically significant."

Three of the teachers mentioned they had problems with the new kind of interaction created by the virtual environment:

T2 - "The lack of face-to-face interaction and the distress in having to type each and every interaction are less touchable problems, though not less important."

T4 - "In the virtual classroom, the main problem is the feeling of isolation provoked by the transactional distance. At the same time 
that the www puts an end to the geographical frontiers, it does not provide face to face interaction. This has resulted in an increase in the dropout rate and many complaints among students that take distance courses."

T5 - "Something that made me feel a bit anxious was a desire to be present, interacting with the group."

Two other very important issues highlighted by the informant teachers were also included as examples of this category. These refer to the prejudice against on-line courses and the changes in the role of the teacher. The excerpts below exemplify the teachers' worries in relation to these issues:

T1 - "There is still a lot of prejudice against those who work with distance methodology, and there are people who think that online courses do not have the same value as standard ones."

T3 - "There is a clear change in relation to the mode of interaction. The fact that teachers and students are not present in the same place, at the same time, requires a new awareness on the side of teachers: an awareness that their role is not to be so omnipresent as they normally are in standard classes. I believe that, in the beginning, it is difficult for both learners and teachers alike to rethink the role and the responsibility of each of them in the teaching/learning process. It is necessary to act more as an advisor and facilitator than as an instructor. [... ] I don't think that such changes would threaten the place or even the importance of the teacher in the process of learning. On the contrary, they highlight how urgent the need is for teachers to be multi-skilled in the roles they have to perform and in the abilities they need to have."

T4 - "In the virtual classroom, the emphasis seems to be on learning. Thus, the teacher now takes the role of the facilitator in the most strict sense of the word. [... ] This type of environment requires the teacher to be a 'virtual entertainer'. The virtual classroom management can't follow the parameters of the standard classroom under the risk of total failure."

T5 - "There is the necessity for the teacher to be informed and attentive to the changes and new technologies. The teacher needs to have technological knowledge that enables him/her to work in this area." 


\section{Conclusion and implications}

As it has been stated previously, technology has come to stay. For this reason, it is important to study the use of technology in teaching, not only to develop better methodologies to be used in virtual classrooms but also to understand the problems that might arise in a virtual environment. Moreover, understanding the nature of problems in a virtual classroom is a necessary requirement for those involved in teacher development and education.

The findings presented here show that teachers face many problems when trying to implement the use of technology in language teaching. These problems may be related to the technology itself or to the virtual environment.

The first set of problems, problems related to the technology, seem to be more concrete and might be solved by investing more money in buying new equipment, hiring adequate technical support and training students in the use of different kinds of software.

The second set of problems, problems related to the virtual environment, however, seem to involve a psychological component. Teachers need to be prepared to face these problems and to adequately perform their new roles.

Medgyes (1994:41) reminds us that

"studies of the language learner are abundant, while those on the
language teacher are much less common. This also applies to research
on personal stress in ELT: whereas books and articles on anxiety in
language learning are in abundance, there is hardly anything written
about 'the sickness to teach' foreign languages. This is a regrettable fact,
considering that anxiety-ridden teachers are likely to raise the students'
anxiety level too. Learning about how to alleviate our own stress is a
precondition for being able to deal with learner stress."

As Mattos (2000) has reported, teachers do find problems and other sources of anxiety in their daily life, and these factors influence the teachers' performance in teaching. The second set of problems reported here in the research findings show that teachers also find difficulties in their virtual classrooms and these difficulties may become a source of anxiety and stress. Claxton's stress cycle presented by Medgyes (1994) warn was about the dangers of teachers becoming stressed and anxiety-driven. Thus, it is necessary to better understand 
the nature of the problems encountered by teachers w orking in a virtual environment and to clearly identify the sources of teachers' anxiety and stress. In this way, it will be possible to prepare teachers to face these problems and to avoid anxiety and stress.

Teacher development courses should try to include a module on CALL, not only with the objective of presenting this new trend and methodology to teachers, but also to try to help teachers cope with the problems and anxieties in facing their new roles in virtual classrooms.

\section{References}

ALMEIDA FILHO, J. C. P. Tendências na formação continuada do professor de língua estrangeira. APLIEMGE: Ensino \& Pesquisa, v.1, p. 29-41, 1997.

AZEVEDO, W. Tecnopólio. A rendição da cultura à tecnologia. [s.p.], 2000. Disponível em: <http://aquifolium.com/sala2/2aunidade.html>. Acesso em 05/09/2000.

BEAUGRANDE, R. Cognition and technology in education: knowledge and information - language and discourse. International Journal of Cognitive Technology, v. 1, n. 2, 2002.

CARVALHO, H. G. Computador: uma caixa de Pandora ou um espetáculo mágico? In: CONGRESSO DA ASSOCIAÇÃO DE PROFESSORES DE LÍNGUA INGLESA DO ESTADO DE MINAS GERAIS \& ENCONTRO DE PROFESSORES DE LÍNGUAS ESTRANGEIRAS DO CEFET-MG, 3, 2001, Belo Horizonte. Anais... Belo Horizonte: APLIEMGE / CEFET-MG, 2001.

CHOMSKY, N. Aspects of the theory of syntax. Cambridge, Mass.: M.I.T. Press, 1965.

CLAXTON, G. Being a teacher. Cassell, 1989.

COURA SOBRINHO, J. Computa dor: uma caixa de Pandora ou uma caixa preta? In: CONGRESSO DA ASSO CIAÇÃO DE PROFESSORES DE LÍNGUA INGLESA DO ESTADO DE MINAS GERAIS\& ENCONTRO DE PROFESSORES DE LÍNGUAS ESTRANGEIRAS DO CEFET-MG, 3, 2001, Belo Horizonte. Anais... Belo Horizonte: APLIEMGE / CEFET-MG, 2001.

CORRÊA, E. F. A Intern et como ferramenta auxiliar em sala de aula de língua inglesa: percepções de duas professoras. 2002. Dissertação (Mestrado em Lingüística Aplicada ao Ensino de Línguas Estrangeiras) - Faculdade de Letras, Universidade Federal de Minas Gerais, Belo Horizonte. 
DEBSKI, R. et al. Language learning through social computing. Merbourne: Applied Linguistics Association of Australia, 1997.

FREEMAN, D. Teacher training, development, and decision making: a model of teaching and related strategies for language teacher education. TESOL Quarterly, v. 23, n. 1, p. 27-45, 1989.

FREEMAN, D. The "unstudied problem": research on teacher learning in language teaching. In: FREEMAN, D.; RICHARDS, J. (Ed.). Teacher learning in language teaching. New York: Cambridge University Press, 1996a.

FREEMAN, D. Redefining the relationship between research and what teachers know. In: BAILEY, K.; NUNAN, D. (Ed.). Voicesfrom thelanguage classroom. New York: Cambridge University Press, 1996b.

FREEMAN, D.; RICHARDS, J.(Ed.). Teacher learning in language teaching. New York: Cambridge University Press, 1996.

GARIGLIO, M. I. Computador: uma caixa de Pandora? In: CONGRESSO DA ASSO CIAÇÃO DE PROFESSORESDE LÍNGUA INGLESA DO ESTADO DE MINAS GERAIS \& ENCONTRO DE PROFESSORES DE LÍNGUAS ESTRANGEIRAS DO CEFET-MG, 3, 2001, Belo Horizonte. Anais... Belo Horizonte: APLIEMGE / CEFET-MG, 2001.

GIMENEZ, T. Learners becoming teachers: an exploratory study of beliefs held by prospective and practising EFL teachers in Brazil. 1994. Tese (Doutorado) - Department of Linguistics and Modern English Language, Lancaster University.

GRAUS, J. An evaluation of the usefulness of the internet in the EFL Classroom. 1999. Dissertação (Mestrado) - Department of English, University of Nijmegen. Disponível em বhttp://home.plex.nl jgraus/thesis/ content/htm>. Acesso em 06/05/2000.

HANSO N-SMITH, E. Computer-assisted language learning. In: CARTER, R.; NUNAN, D. (Ed.). The Cambridge guide to teaching English to speakers of other languages. Cambridge: Cambridge University Press, 2001.

HOLLIDAY, A. Appropriate methodology and social context. Glasgow: Cambridge University Press, 1994.

KOOK, J. Computers and communication networks in educational settings in the twenty-first century: preparation for educators' new roles. Educational Technology, Englew ood Cliffs, p. 56-60, Mar./Apr. 1997.

LEVY, M. Computer assisted language learning. Oxford: Claredon, 1997. 
LIGHTBOWN , P. M.; SPADA, N. How languagesarelearned. Hong Kong: Oxford University Press, 1993.

LONG, M. Inside the "black box": methodological issues in research on language teaching and learning. Language Learning, v. 30, p. 1-42, 1980.

MATTOS, A. M. A. Percepções de uma professora de inglês sobre sua sala de aula: uma visão êmica. 2000. (Dissertação em Lingüística Aplicada ao Ensino de Línguas Estrangeiras) - Faculdade de Letras, Universidade Federal de Minas Gerais, Belo Horizonte.

MATTOS, A. M. A. Percepções sobre a sala de aula de língua estrangeira: uma visão global e êmica. Revista de Estudos da Linguagem, Belo Horizonte, v. 10, n. 1, p. 109-138, jan./jun. 2002.

MEDGYES, P. The non-native teacher. Hong Kong: Macmillan, 1994.

MOITA LOPES, L. P. Oficina deLíngüística Aplicada. Campinas: Mercado das Letras, 1996.

PAIVA, V. L. M. O. A WWW e o Ensino de Inglês. Revista Brasileira de Lingüística Aplicada, v. 1, n. 1, p. 93-116, $2001 a$.

PAIVA, V. L. M. O. A sala de aula tradicional $x$ a sala de aula virtual. In: CONG RESSO DA ASSO CIAÇÃO DE PROFESSORES DE LÍNGUA INGLESA DO ESTADO DE MINAS GERAIS \& ENCONTRO DE PROFESSORES DE LÍNGUAS ESTRANGEIRAS DO CEFET-MG, 3, 2001, Belo Horizonte. Anais... Belo Horizonte: APLIEMGE / CEFET-MG, 2001b.

RICHARDS, J. C.; NUNAN, D. (Ed.). Second language teacher education. New York: Cambridge University Press, 1990.

STERN, H. H. Fundamental concepts of language teaching. Hong Kong: Oxford University Press, 1983.

VIEIRA, S. Educação cai na rede: boom do ensino à distância gera questionamentos sobre as condições de trabalho dos professores. Jornal Extra-Classe, n. 104, jan./jul., Belo Horizonte: Sindicato dos Professores de Minas Gerais, p. 6, 2002.

WARSCHAUER, M. E-mail for English teaching. Alexandria: TESO L, 1995.

WARSCHAUER, M. et al. Internetfor English teaching. Alexandria: TESOL, 2000.

WOODS, D. Teacher cognition in languageteaching: beliefs, decision-making and classroom practice. Cambridge: Cambridge University Press, 1996. 